\title{
Harmless Error as Constitutional Common Law: Congress's Power to Reverse Arizona $v$ Fulminante
}

\author{
Craig Goldblatt $\dagger$
}

When the Supreme Court announced in Arizona $v$ Fulminante ${ }^{1}$ that the introduction of a coerced confession into evidence in criminal trials may be treated as "harmless error," critics attacked the decision as a crabbed reading of the Constitution's grand protections of the rights of the criminally accused. The Los Angeles Times reported that the Court "knocked down one of the pillars of constitutional law,"2 and complained that the decision "seriously eroded one of the Constitution's fundamental protections." Steven Shapiro, Associate Director of the American Civil Liberties Union, said that the case reflected the Rehnquist Court's increased willingness "to balance fundamental constitutional rights against the desire to preserve and uphold criminal convictions."4 Even Justice Stevens added to the chorus: "an extraordinarily aggressive Supreme Court has reached out to announce a host of new rules narrowing the federal Constitution's protection of individual liberties. The prosecutor's use of a coerced confession-no matter how vicious the police conduct may have been-may now constitute harmless error."

These criticisms reflect the now-predominant understanding of the harmless error rule as being a doctrine of constitutional law. They each assume that the Supreme Court decisions that expand the scope of harmless error analysis by the same token contract the sweep of constitutional rights.

$\dagger$ B.A. 1990, Georgetown University; J.D. 1993, The University of Chicago.

111 S Ct 1246 (1991).

2 David G. Savage, High Court Allows Forced Confessions in Criminal Trials; Judiciary: A Key Pillar of Constitutional Law is Upset. Justices, in 5-4 Vote, Rule That a Coerced Admission of Guilt Could be Used if it Amounts to a "Harmless Error," LA Times A1 (Mar 27, 1991).

"Justices Open Pandora's Box; Out Comes the "Harmless" Forced Confession, LA Times B6 (Mar 28, 1991).

- Dawn Ceol, High Court Allows Tainted Confessions, Wash Times A1 (Mar 27, 1991).

- John Paul Stevens, The Bill of Rights: A Century of Progress, 59 U Chi L Rev 13, 16 (1992), citing Fulminante, $111 \mathrm{~S}$ Ct 1246. 
This Comment takes issue with this conventional understanding of the harmless error doctrine. Though widely (albeit often only tacitly) accepted today, this view is entirely inconsistent with the history and purposes of the harmless error doctrine. Instead, the harmless constitutional error rule is only "constitutional common law"-a judicially created prophylactic rule designed to protect constitutional rights, but not itself an interpretation of the Constitution. ${ }^{6}$

This distinction raises an important question about the extent of Congress's powers. Whether Congress has the constitutional authority to reverse the Court's decision in Arizona $v$ Fulminante may depend on whether the harmless error doctrine can be characterized as constitutional common law. This question is now of more than mere academic interest, because a bill that purports to reverse Fulminante was subsequently introduced in Congress. ${ }^{7}$

This Comment argues that because the harmless error doctrine should be understood as constitutional common law, Congress has the constitutional authority to enact this legislation, thereby forbidding appellate courts from treating the introduction of an involuntary confession as harmless error, even in state court proceedings. Congress's power to impose such a requirement on the states derives straightforwardly from Section 5 of the Fourteenth Amendment, which grants Congress the power to enact legislation to "enforce" the due process and equal protection guarantees. By contrast, if the harmless error doctrine were viewed as an interpretation of the Constitution, Congress would have constitutional authority to reverse Fulminante only if Section 5 were read rather broadly.

A proper understanding of the nature of the harmless error doctrine, however, would avert disputes over the scope of Congress's Section 5 power. Because the harmless constitutional error rule is just a constitutional common law doctrine, Congress has the power, under Section 5, to provide a remedy for the violation of constitutional rights. This type of legislation does not raise difficult questions about the scope of the Section 5 power.

In Section I, this Comment briefly addresses Congress's Section 5 powers and explains why Congress plainly has the power to reverse Fulminante if the harmless error doctrine is divorced from

\footnotetext{
- See generally Henry P. Monaghan, The Supreme Court, 1974 Term-Foreword: Constitutional Common Law, 89 Harv L Rev 1 (1975).

3 Omnibus Crime Control Act of 1991, HR 3371, 102d Cong, 1st Sess (Sep 23, 1991), in 137 Cong Rec 7916 (Oct 16, 1991).
} 
constitutional law. The balance of the Comment argues for such a separation. Section II examines the history and mechanics of the harmless error doctrine, arguing that the harmless constitutional error doctrine arose as a prophylactic rule designed to protect underlying constitutional rights. Section III explains how the doctrine has come to be seen-mistakenly-as a matter of constitutional law. This Section instead contends that the harmless error rule should be treated as a judicially created prophylaxis, rather than as part of the Constitution itself. Congress may therefore reverse the Court's decision in Arizona $v$ Fulminante through ordinary legislation.

\section{The Extent of Congress's Powers}

\section{A. Congress's Effort to Reverse Fulminante}

The Supreme Court in Arizona v Fulminante ${ }^{8}$ held that the introduction of a coerced confession into evidence may be treated as harmless error. Congress considered overturning the decision: Title IX of the Omnibus Crime Control Act of 1991 provided that "the admission of a coerced confession in a state or federal trial shall never be considered harmless error and will require automatic reversal of a conviction." Because Title IX defined a coerced confession as one obtained in violation of either the Fifth or the Fourteenth Amendments, the provision not only reached the federal courts, but also would have prevented state appellate courts from treating the admission of a coerced confession as harmless. In sum, this law would have reversed Arizona o Fulminante. ${ }^{10}$

But while the Supreme Court's decision in Fulminante was front-page news, ${ }^{11}$ sparking a great deal of editorial debate, ${ }^{12}$ Con-

- 111 S Ct 1246.

- 137 Cong Rec at 7916. The conference committee amended the bill, moving the "coerced confessions" provision from Title IX to Title IV. See 137 Cong Rec 11,686 (Nov 26, 1991).

${ }^{10}$ If the text of the statute were not clear enough, the committee report removes all doubt, noting that "[t]his title reinstates the law in effect prior to the Supreme Court's decision in Arizona $v$ Fulminante . . . as it relates to the effect of the admission at trial of a coerced confession." Omnibus Crime Control Act of 1991, HR Rep No 102-242, 102d Cong, 1st Sess 109 (1991).

${ }^{11}$ Linda Greenhouse, High Court, 5 to 4, Softens Stand Against Confession by Coercion, NY Times A1 (Mar 27, 1991); Ruth Marcus, Court Splits on Coerced Confessions; Majority Rules Use of Statement Can Be "Harmless Error," Wash Post A1 (Mar 27, 1991); Savage, High Court Allows Forced Confessions at A1 (cited in note 2).

${ }^{12}$ See The Supreme Court's Harmful Error, NY Times A22 (Mar 29, 1991); A Supreme Court Retreat, Wash Post A20 (Mar 29, 1991); Justices Open Pandora's Box at B6 (cited in note 3). 
gress's rather extraordinary effort to reverse the decision went completely unnoticed. Public attention focused on provisions of the Crime Control Act that would have imposed a seven-day mandatory waiting period on handgun purchases (the Brady Bill) and extended the federal death penalty to fifty-three new crimes; meanwhile, Title IX was never mentioned in a major newspaper. ${ }^{13}$ In any case, the National Rifle Association fiercely opposed the Brady Bill, and with the threat of a presidential veto in the background, the legislation died after attempts to end a Republican-led filibuster in the Senate failed. ${ }^{14}$

Still, during the 1992 presidential campaign, President Clinton emphasized crime-control legislation as a centerpiece of his legislative program, and-while he made no mention of Title IX-even indicated that he would use the 1991 Crime Control Act as a model. ${ }^{15}$ The question presented by the legislation therefore remains timely: Does Congress have the constitutional authority to reverse the Supreme Court's decision in Fulminante?

\section{B. The Three Models of Congress's Section 5 Power}

The congressional effort to require states to grant new trials to criminal defendants against whom coerced confessions are introduced is best seen as an exercise of the powers granted to Congress by Section 5 of the Fourteenth Amendment. ${ }^{16}$ The question of

1s See Clifford Krauss, After Senate Backs Bush and Blocks Anti-Crime Bill, Congress Goes Home, NY Times D22 (Nov 28, 1991); Guy Gugliotta, Senate GOP Stalling Defeats Crime Bill; House Passes Measure Bush Called Too Soft, Wash Post A41 (Nov 28, 1991); Paul Houston, Crime Bill Succumbs to Republican Senate Filibuster; Congress: \$3.1-Billion Measure Had Been Resurrected by House Democrats; Battle Illustrates Election-Year Potency of Issue, LA Times A30 (Nov 28, 1991).

14 See Gugliotta, Senate GOP Stalling at A41.

18 See Morton M. Kondracke, Clinton, Congress Must Tackle Crime in the First Hundred Days, Roll Call 6, 15 (Dec 10, 1992) ("Clinton transition officials anticipate Clinton will act swiftly on crime but point out that he has to decide how much money to spend on it and how extensively to change the 1991 bill."). During the second presidential debate, Clinton faulted the Republican filibuster on the 1991 Crime Bill. "There is a crime bill . . . which was killed for this session by a filibuster in the Senate, mostly by Republican senators, and I think it's a shame it didn't pass, I think it should be made the law . . . "Campaign '92: Transcript of the Second Presidential Debate (Part I), Wash Post A34 (Oct 16, 1992).

16 Alternatively, one might contend that Congress's Commerce Clause power supports this enactment. See US Const, Art I, § 8, cl 3; Heart of Atlanta Motel v United States, 379 US 241 (1964); Katzenbach v McClung, 379 US 294 (1964). But while Congress's commerce powers are certainly extensive, it is far from clear that they extend to determining the harmlessness standard to be employed by state appellate courts. For example, this exercise of the commerce power would have to evade the confused constitutional limitations on Congress's power to regulate "States qua States." See National League of Cities v Usery, 426 US 833, 847 (1976); Garcia v San Antonio Metropolitan Transit Authority, 469 US 528 
whether Congress has the power to impose such a requirement on the states, then, turns on how broadly one reads this Section 5 power.

Section 5 grants Congress the "power to enforce, by appropriate legislation, the provisions of [the Fourteenth Amendment]."1z The Supreme Court has not clearly demarcated the precise boundaries of Congress's Section 5 powers. Instead, there are three different ways of understanding the breadth of this power, described here as three "models" of the Section 5 power.

\section{Model 1: remedial powers.}

Under the first model, Congress can "enforce" the Fourteenth Amendment by providing remedies for recognized violations of its provisions. For instance, in South Carolina $v$ Katzenbach, ${ }^{18}$ the Court upheld the provisions of the Voting Rights Act of 1965 that set out an intricate remedial regime in cases where "the [Constitution] has clearly been violated."19 Once the violation of a Fourteenth Amendment right has been established, it is well-accepted that Section 5 empowers Congress to enact legislation to provide an appropriate remedy. ${ }^{20}$

2. Model 2: analogy to "necessary and proper" powers.

The second model views Congress's Section 5 powers as analogous to its powers under the Necessary and Proper Clause. ${ }^{21}$ Just as the Necessary and Proper Clause permits Congress to employ any appropriate means to give effect to the ends specified in or implied by the enumerated powers, ${ }^{22}$ Section 5 empowers Congress to enact legislation to give effect to the Fourteenth Amendment's due process and equal protection guarantees.

(1985); New York v United States, 112 S Ct 2408 (1992). A full examination of this question is beyond the scope of this Comment.

${ }^{17}$ US Const, Amend XIV, § 5 .

18 383 US 301 (1966).

10 Id at 334. In the Voting Rights Act of 1965 , Congress exercised its power under $\S 2$ of the Fifteenth Amendment to "enforce . . . by appropriate legislation" the rights the Fifteenth Amendment guarantees. US Const, Amend XV, $\$ 2$. Section 2 of the Fifteenth Amendment uses essentially the same language as Section 5 of the Fourteenth Amendment, and the cases have not distinguished between the enforcement powers granted by these two provisions. See Laurence H. Tribe, American Constitutional Law § 5-14 at 340 (Foundation, 2d ed 1988).

${ }^{20}$ Katzenbach, 383 US at 341.

21 See US Const, Art I, $\$ 8$, cl 18.

"See McCulloch v Maryland, 17 US (4 Wheat) 316 (1819). 
Thus, under this model, Congress may take action to prevent a threatened Fourteenth Amendment violation. For example, while the Constitution forbids only purposeful discrimination, ${ }^{23}$ the Supreme Court in City of Rome $v$ United States ${ }^{24}$ permitted Congress to employ the remedial measures of the Voting Rights Act against changes in election procedures that have only a disproportional impact, without requiring the showing of intentional discrimination necessary to find an actual constitutional violation. The Court concluded that "because electoral changes by jurisdictions with a demonstrable history of intentional racial discrimination in voting create the risk of purposeful discrimination, it was proper to prohibit changes that have a discriminatory impact."25 Congress therefore has the power, under Section 5, to "establish a prophylactic rule-almost a rule of evidence"-designed to safeguard constitutional rights from state invasion. ${ }^{26}$ This second model is somewhat broader and more controversial than the first.

\section{Model 3: "reinterpretive" powers.}

Under the third model, Congress has the power to act whenever it decides the Fourteenth Amendment is being violated. Instead of holding Congress to the Court's interpretation of the Fourteenth Amendment, this model permits Congress to "reinterpret" the due process and equal protection guarantees-to decide what is and is not forbidden by the Constitution. ${ }^{27}$ This is a far broader model of the Section 5 power than the other two; for this reason, the third model is also the most controversial.

${ }^{23}$ City of Mobile $v$ Bolden, 446 US 55 (1980).

24 446 US 156 (1980).

${ }^{25}$ Id at 177 .

28 Tribe, American Constitutional Law $\S 5-14$ at 338 (cited in note 19).

${ }^{27}$ Even under this model there would remain questions about whether a given legislative enactment can be seen as a means to "enforce" the Fourteenth Amendment. In particular, it is unclear whether legislation that would limit or dilute the equal protection and due process guarantees would be authorized by Section 5. See Katzenbach v Morgan, 384 US 641, 651-52 n 10 (1966). But see Title II of the Omnibus Crime Control and Safe Streets Act of 1968, 18 USC $\$ 3501$ (1988) (purporting to reverse, in part, the Court's decision in Miranda $v$ Arizona by allowing a judge to determine whether a confession is "involuntary"); Robert A. Burt, Miranda and Title II: A Morganic Marriage, 1969 S Ct Rev 81 (suggesting that Title II is a valid exercise of Congress's Section 5 power). See also United States $v$ Crocker, 510 F2d 1129, 1137-38 (10th'Cir 1975) (raising, but failing to dispose of, the constitutional questions posed by Title II); Cooper v Dupnik, 963 F2d 1220, 1257 (9th Cir 1992) (Leavey dissenting) ("Neither the Supreme Court nor this court has held that 18 USC $\S 3501$ is unconstitutional."). 
4. Choosing among the competing models.

It is unclear which of these models best describes the current state of the law. At the least, Congress has the powers described by Model 1. But Congress may have greater powers. The leading case on the breadth of the Section 5 power, if it remains good law, can be read to grant Congress the powers described by either Model 2 or Model 3.

In Katzenbach $v$ Morgan, ${ }^{28}$ the Court addressed the constitutionality of $\S 4(\mathrm{e})$ of the Voting Rights Act of 1965, which forbade states to deny any citizen who has completed a sixth grade education in a Puerto Rican school the right to vote on account of her inability to read and write English. Although the Supreme Court had earlier found in Lassiter $v$ Northampton County Board of Elections $^{29}$ that a New York law requiring all voters to demonstrate English-language literacy did not violate the Fourteenth Amendment, the Morgan Court held that this section of the Voting Rights Act was a valid exercise of the Section 5 power. ${ }^{30}$

This holding rested on two alternative theories, each of which reflects a competing model of the scope of Congress's Section 5 powers. The first, narrower theory reflects the Model 2 understanding of Section 5. On this view, Congress could determine that, even though the use of voting tests did not violate the Constitution, many Puerto Ricans were the victims of other forms of official discrimination that did violate the Equal Protection Clause. Section 4(e) of the Voting Rights Act could be justified as a means of preventing this discrimination, because giving Puerto Ricans the right to vote would empower the group to resist discriminatory treatment in these other contexts. ${ }^{31}$

In the alternative, the Morgan Court offered an even more farreaching and controversial theory, one reflecting the Model 3 understanding of the Section 5 power. Under this approach, Congress had the authority to determine that the use of the literacy test itself violated the Fourteenth Amendment. Section 4(e) of the Voting Rights Act, then, was a remedy for what Congress considered to be a violation of the Fourteenth Amendment, even though the Court in Lassiter had found no constitutional violation in analogous circumstances.

\footnotetext{
28384 US 641 (1966).

20 360 US 45 (1959).

so 384 US at 652 .

s1 See Tribe, American Constitutional Law \$ 5-14 at 341-42 (cited in note 19).
} 
The scope of Congress's Section 5 powers, then, remains uncertain. Section 5 indisputably grants Congress those powers described by Model 1. Whether Congress also has the Model 2 or Model 3 powers is a contested question. The Model 3 powers are the least certain. In Morgan, the Model 3 approach was an alternative grounds for the decision, and other than Morgan itself, the Court has never upheld an act of Congress under this "reinterpretive" theory. In fact, in Oregon $v$ Mitchell, ${ }^{32}$ a plurality of the Court struck down a congressional attempt (which would be permissible under Model 3) to require states to permit eighteen-yearolds to vote in state elections. ${ }^{33}$ By contrast, the Court has affirmed legislation (without agreeing on a theory) that is best seen as an exercise of Model 2 powers. ${ }^{34}$

Resolving the debate over Section 5 is beyond the scope of this Comment. ${ }^{35}$ In any case, according to the understanding of harmless error for which this Comment argues, legislation reversing Fulminante would be constitutional even if Congress's powers were limited to those encompassed by Model 1.

For this reason, a great deal turns on how the harmless error rule is understood. If harmless error and the Court's decision in Fulminante are explications of the Constitution, then the constitutionality of Congress's attempted reversal of Fulminante hinges on which model of Section 5 is adopted. That is, the "constitutional law" understanding of Fulminante would be that the Constitution is not violated by the introduction of a coerced confession against a criminal defendant that is harmless beyond a reasonable doubt. In reversing Fulminante, Congress would require state courts to grant new trials even where, according to the Supreme Court, the Consti-

32400 US 112 (1970).

ss This purpose, of course, was ultimately accomplished by the ratification of the 26th Amendment.

st In addition to City of Rome, 446 US at 156, see, for example, Metro Broadcasting $v$ FCC, 497 US 547 (1990).

ss The Court may soon be required to clarify the extent of Congress's Section 5 powers. While this Comment argues that the constitutional question need not be reached by the effort to reverse Fulminante, legislation is pending that purports to reverse a number of Rehnquist Court decisions that narrowed the scope of constitutional rights. See, for example, the Religious Freedom Restoration Act of 1991, HR 2797, 102d Cong, 2d Sess (Jun 26, 1991) (responding to Employment Division v Smith, 494 US 872 (1990)); Racial Justice Act, S 1244, 102d Cong, 1st Sess (Jun 6, 1991) (responding to McCleskey v Kemp, 481 US 279 (1987)); Freedom of Choice Act, S 25, 102d Cong, 1st Sess (Jan 14, 1991), in 137 Cong Rec 642 (Jan 14, 1991). See generally, Comment, When the Supreme Court Restricts Constitutional Rights, Can Congress Save Us? An Examination of Section 5 of the Fourteenth Amendment, $141 \mathrm{U} \mathrm{Pa}$ I Rev 1029 (1993). The constitutionality of such legislation will turn on which model of Section 5 the Court adopts. 
tution has not been violated-where introduction of the confession was harmless beyond a reasonable doubt. This legislation is unconstitutional under Model 1, since there has been no constitutional violation to remedy ${ }^{36}$ Under Model 2 it is a close question. Is it a "necessary and proper" means to safeguard against coerced confessions? If so, it is permissible. Model 3, of course, presents the easiest case, since Congress would be permitted to "reinterpret" what the constitution requires.

Yet, a proper understanding of the harmless error doctrine eliminates the need to choose among the competing models. If the harmless error rule is understood as a judicially-created prophylactic rule, rather than as a matter of constitutional law, then Title IX becomes a non-controversial exercise of those powers plainly granted to Congress regardless of the Section 5 model chosen. The balance of this Comment argues for such an understanding of the harmless error doctrine.

\section{Harmless Constitutional Error}

The rule governing whether and how constitutional errors may be treated as harmless traces its origins to the common law harmless error doctrine that has long governed the way in which appellate courts have treated erroneous applications of the rules of evidence. While it perhaps should not be surprising that this common law doctrine of "harmless error" would be brought to bear on constitutional violations, it is interesting to note how later cases that have filled in the contours of the doctrine-except for one case last term $^{37}$-appear to treat the "harmless constitutional error" rule as if they were interpreting the constitutional guarantees themselves.

\section{A. The Origins of the Harmless Error Doctrine}

The harmless error doctrine stems from the principle that remedies should be roughly proportional to the injury caused by the violation. The orthodox English rule, articulated in Doe $v$ Tyler ${ }^{38}$ required an appellate court to affirm a conviction, error notwithstanding, so long as "there [was] enough to warrant the finding of the jury independently of the evidence objected to."39 In

\footnotetext{
36 At least the bill's constitutional validity would be highly questionable; Congress probably lacks the power to regulate state criminal procedure under the Commerce Clause. See note 16.

37 See Brecht v Abrahamson, 113 S Ct 1710 (1993).

286 Bing 561, 130 Eng Rep 1397 (Common Pleas 1830).

30 Id at 1398.
} 
other words, as long as untainted evidence supported the jury's finding, the appellate court was to ignore the error. English courts rejected this rule in the mid-1800s, largely out of a sense that the rule provided inadequate remedies - thereby allowing the underlying rights to be violated with impunity. "[F]requent application" of the harmless error rule of Doe v Tyler, courts feared, "would cause the rules of evidence to be less carefully considered." $" 40$

The Exchequer Rule, under which all errors required a reversal and a new trial, thus replaced the orthodox English rule. ${ }^{41}$ But this rule, it was widely thought, tipped the balance too far in the other direction. ${ }^{42}$ Because even the most trivial errors would be grounds to order a new trial, criminal trials "became a game for sowing reversible error in the record." 43 The remedy for error-a new trial-often far exceeded the injury that the error inflicted on the defendant. Litigation could "survive until the parties expired." Parliament responded to this situation by enacting the Judicature Act of 1873, under which new trials were not to be ordered unless "some substantial wrong or miscarriage" resulted from the error. ${ }^{45}$

Because the rigid Exchequer Rule had also taken hold in the United States, ${ }^{46}$ Congress enacted a federal harmless error statute in 1919.47 The statute directed federal appellate courts to ignore errors that did not "affect the substantial rights of the parties." 48 In cases involving non-constitutional errors, this language requires a new trial whenever the error "had substantial and injurious effect or influence in determining the jury's verdict." 49 All fifty states have adopted harmless error rules. ${ }^{\mathrm{BO}}$

10 Crease v Barrett, 1 CM \& R 919, 149 Eng Rep 1353, 1359 (Ex Div 1835).

41 Roger J. Traynor, The Riddle of Harmless Error 8 (Ohio State, 1970).

${ }^{42}$ Steven H. Goldberg, Harmless Error: Constitutional Sneak Thief, $71 \mathrm{~J}$ Crim L \& Criminology 421, 422 (1980).

is Kotteakos v United States, 328 US 750, 759 (1946).

44 Goldberg, $71 \mathrm{~J}$ Crim L \& Criminology at 422.

45 Traynor, The Riddle of Harmless Error at 8-9.

48 Id at 13.

4740 Stat 1181 (1919), amended version codified at 28 USC § 2111 (1988).

48 Id.

49 Kotteakos, 328 US at 776.

so Chapman v California, 386 US 18, 22 (1967). This unusual history is significant because the relationship between the underlying rights and harmless error analysis should perhaps be seen as analogous to the relationship between causes of action against government officers and the doctrines of official immunity. In that context, Justice Scalia has written that the immunities available to a government officer being sued under $\S 1983$ should be precisely those that were available at the time the underlying cause of action was created. Thus, in the $\S 1983$ context, the question is whether the immunity being claimed would 
B. Harmless Constitutional Error and the Applicability of Federal Law

Until the 1960s, it was widely thought that errors involving the deprivation of constitutional rights could never be treated as harmless error. ${ }^{51}$ Ironically, this assumption was refuted at the peak of the Warren Court's expansion of the rights of criminal defendants, and particularly as the guarantees of the federal constitution were first being applied to regulate state criminal procedure. ${ }^{.2}$

The Court first expressly addressed harmless constitutional error in Fahy $v$ Connecticut. ${ }^{53}$ There, a state court concluded that a violation of the recently announced exclusionary rule ${ }^{54}$ was harmless, applying the state's own harmless error rule. ${ }^{55}$ The Court reversed, finding that the error did prejudice the defendant. The majority therefore thought it unnecessary to reach the question of whether constitutional violations could ever be treated as harmless..$^{\text {sB }}$

But on what grounds did the Court reverse? One commentator has suggested that the Court decided that the Connecticut court misapplied the state statute. ${ }^{87}$ For this to be true, the Court would have had to ignore the accepted principle that it will not tamper

have been available when the Civil Rights Act was enacted in 1871. See Burns $v$ Reed, $111 \mathrm{~S}$ Ct 1934, 1945 (1991) (Scalia concurring). By contrast, if the underlying cause of action against the government officer is brought under Bivens $v$ Six Unknown Named Agents of Fed. Bur. of Narc., 403 US 388 (1971), the question would turn on what immunities would have been available in 1971 . See Burns, $111 \mathrm{~S} \mathrm{Ct}$ at $1946 \mathrm{n} \mathrm{1.} \mathrm{On} \mathrm{this} \mathrm{view,} \mathrm{the} \mathrm{type} \mathrm{of}$ harmless error analysis applicable to the violation of an underlying constitutional right should turn on the state of the harmless error doctrine at the time of the creation of the constitutional right.

s1 See Kotteakos, 328 US at 764-65 ("[if] the error did not influence the jury, or had but very slight effect, the verdict and the judgment should stand, except perhaps where the departure is from a constitutional norm"); Yale Kamisar, Wayne R. LaFave and Jerold H. Israel, Modern Criminal Procedure: Cases, Comments and Questions 1500 (West, 7th ed 1990) ("Prior to the 1960's, it generally was assumed that constitutional violations could never be regarded as harmless error."). For an argument that constitutional errors should not be amenable to harmless error analysis, see Goldberg, $71 \mathrm{~J}$ Crim L \& Criminology at 421-22 (cited in note 42).

s2 See, for example, Mapp v Ohio, 367 US 643, 655 (1961) (applying the exclusionary rule to the states); Miranda v Arizona, 384 US 436, 467-69 (1968) (finding that the Fifth Amendment required the police to inform criminal defendants of their right to silence and counsel).

375 US 85 (1963).

4 See Mapp, 367 US 643.

ss Connecticut v Fahy, 149 Conn 577, 183 A2d 256, 261-62 (1962).

sa Fahy, 375 US at 86.

s7 Note, Harmless Constitutional Error, 20 Stan L Rev 83, 86-87 (1967). 
with a state court's interpretation of state law. ${ }^{58}$ Nor did the Court's cryptic opinion declare the federal harmless error statute applicable. While Justice Harlan, in dissent, pointed to the issue, he found that it need not be answered since Connecticut's harmless error standard was as strict as any federal standard. ${ }^{58}$

The Court resolved the question of harmless constitutional error in Chapman $v$ California. ${ }^{60}$ The defendants in Chapman were charged with robbery, kidnapping and murder. ${ }^{61}$ They elected not to testify on their own behalf, and the prosecutor, as the Constitution and California law then permitted, suggested in his argument to the jury that they draw an inference of guilt from the defendants' silence. ${ }^{62}$ The trial judge instructed the jury that drawing such an inference would be permissible, and the jury returned guilty verdicts. ${ }^{63}$ One defendant was sentenced to life imprisonment and the other to death. ${ }^{64}$

Shortly after the trial court imposed these sentences in Chapman, the Supreme Court in Griffin v California ${ }^{65}$ ruled that the Fifth Amendment's Self-Incrimination Clause forbids both prosecutorial comment on the accused's silence and any instruction from the court permitting the jury to treat the defendant's silence as evidence of his guilt. While the California Supreme Court recognized that the comments and instructions in Chapman violated the rule set out in Griffin, it applied an expansive state harmless error rule under which new trials were not to be ordered unless "the error complained of has resulted in a miscarriage of justice." Accordingly, it found the errors harmless and affirmed the convictions. ${ }^{67}$

The Supreme Court, in an opinion by Justice Black, reversed, declaring that a federal harmless error rule should apply to violations of constitutional rights. ${ }^{68}$ The Court first noted that the error

\footnotetext{
${ }^{88}$ See Murdock v Memphis, 87 US (20 Wall) 590, 626 (1874); R.A.V. v St. Paul, $112 \mathrm{~S}$ Ct 2538, 2542 (1992); Philip J. Mause, Harmless Constitutional Error: The Implications of Chapman v. California, 53 Minn L Rev 519, 522 (1969).

${ }^{80}$ Fahy, 375 US at 95 n 2 (Harlan dissenting). Note that this response also ignores the Murdock v Memphis principle, since the Connecticut court said that under the Connecticut standard, this error was harmless.

${ }^{60} 386$ US 18 (1967).

61 Id at 19.

${ }^{62}$ Id.

ss Id at 18-19.

b4 Id at 19.

${ }^{65} 380$ US 609, 615 (1965).

${ }^{88} \mathrm{Cal}$ Const, Art VI, $\S 41 / 2$ (repealed 1966).

${ }^{67}$ Chapman, 386 US at 20.

${ }^{68}$ Id at 21.
} 
at issue "was a denial of rights guaranteed against invasion by the Fifth and Fourteenth Amendments, rights rooted in the Bill of Rights, offered and championed in the Congress by James Madison, who told the Congress that the 'independent' federal courts would be the 'guardians of those rights." "6o

Protecting federal rights, the Court continued, is the responsibility of the federal government:

Whether a conviction for crime should stand when a State has failed to accord federal constitutionally guaranteed rights is every bit as much of a federal question as what particular federal constitutional provisions themselves mean, what they guarantee, and whether they have been denied. With faithfulness to the constitutional union of the States, we cannot leave to the States the formulation of the authoritative laws, rules, and remedies designed to protect people from infractions by the States of federally guaranteed rights. ${ }^{70}$

Thus, federal law was to govern. But what federal law? The Court declared that until Congress said otherwise, it would announce a standard to fill the void: "We have no hesitation in saying that the right of these petitioners not to be punished for exercising their Fifth and Fourteenth Amendment right to be silent-expressly created by the Federal Constitution itself-is a federal right which, in the absence of appropriate congressional action, it is our responsibility to protect by fashioning the necessary rule."'1

Justice Harlan dissented, arguing that the Court lacked authority to announce a general federal law of harmless constitutional error. Wrote Harlan:

The key to the Court's opinion can, I think, be found in its statement that it cannot "leave to the States the formulation of authoritative laws, rules, and remedies designed to protect people from infractions by the States of federally guaranteed rights" and that "in the absence of appropriate congressional action," the Court must fashion protective rules. The harmless-error rule now established flows from what is seemingly regarded as a power inherent in the Court's constitutional responsibilities rather than from the Constitution itself. The Court appears to acknowledge that other harmless-error for-

\footnotetext{
6 Id.

70 Id.

72 Id (emphasis added).
} 
mulations would be constitutionally permissible. It certainly indicates that Congress, for example, could impose a different formulation.

I regard the Court's assumption of what amounts to a general supervisory power over the trial of federal constitutional issues in state courts as a startling constitutional development that is wholly out of keeping with our federal system and completely unsupported by the Fourteenth Amendment where the source of such a power must be found. ${ }^{22}$

In Justice Harlan's view, the role of the Supreme Court should be limited to ensuring that states are not using their harmless error rules to "destroy or dilute constitutional guarantees." as the states do not, the Court "has no power [ ] to declare which of many admittedly constitutional alternatives a State may choose." "74 The imposition of a uniform national rule, Justice Harlan insisted, "would destroy that opportunity for broad experimentation which is the genius of our federal system." 75

While both Justice Harlan and contemporary commentators ${ }^{78}$ read the majority's opinion as asserting a "general supervisory power" over the administration of criminal justice, this view overstates the scope of the Chapman Court's decision. More narrowly understood, the Court simply declared that it is the province of federal law to assure that federal rights are adequately protected. Congress could, exercising its Section 5 powers, interpose a standard aimed at protecting these rights. In the absence of such congressional action, however, the Chapman Court took it upon itself to fashion such a prophylactic rule.

Some commentators have been troubled by the fact that in announcing a federal harmless error rule, the Court overlooked the existing federal harmless error statute. ${ }^{77}$ According to Justice Traynor, the "most plausible explanation is that the Court lost sight of the controlling federal statute. It is hardly plausible that the Court did not deem [the federal harmless-error statute] 'appropriate congressional action." "78 For Traynor, the Court's task ought to have been one of statutory construction, determining the

72 Id at 46-47 (Harlan dissenting).

73 Id at 50.

74 Id at 48 .

78 Id.

76 See, for example, Mause, 53 Minn L Rev at 533-34 (cited in note 58); Note, 20 Stan L Rev at $88 \mathrm{n} 40$ (cited in note 57).

7228 USC \& 2111 (1988).

${ }^{78}$ Traynor, The Riddle of Harmless Error at 42 (cited in note 41 ). 
meaning of "errors or defects which do not affect substantial rights."79

Yet Traynor glosses over the interesting interpretive question presented by $\S 2111$. The applicability of $\S 2111$ to state deprivations of federal constitutional rights was by no means obvious and is far beyond what Congress likely intended when the statute was enacted. First, like the contemporary state harmless error statutes, $\S 2111$ was designed to govern violations of the rules of evidence, not constitutional errors. In fact, until Chapman itself, it was not even clear that constitutional violations could ever be treated as harmless.

Second, § 2111 was intended to govern the procedures in federal appellate courts, not to set out a harmless error standard to bind the states. ${ }^{80}$ In 1919 , when $\S 2111$ was enacted, few would have thought that Congress had the power, under Section 5, to declare what harmless error standard state appellate courts should apply. ${ }^{81}$ Thus, while perhaps the Chapman Court should have taken account of changed circumstances and "translated" the federal harmless error statute to apply to constitutional errors in the state courts, ${ }^{82}$ the Chapman Court's decision to ignore the statute altogether is not necessarily the "oversight" that Traynor claims. ${ }^{83}$

In any case, the standard set out in Chapman should displace state harmless error rules only where the errors involve the violation of federal constitutional rights. In Cooper $v$ California, ${ }^{84}$ decided the same day as Chapman, the Court declared that states are free to apply their own harmless error rules to errors of state law. As the Cooper Court stated: "There being no federal constitutional error here, there is no need for us to determine whether the lower court properly applied its state harmless-error rule." ${ }^{\text {"Bs }}$

28 USC \& 2111.

so Charles T. McCormick, McCormick on Evidence $\S 182$ at 534 (West, 3d ed 1984).

1 See Archibald Cox, Foreword: Constitutional Adjudication and the Promotion of Human Rights, 80 Harv L Rev 91, 106, 108 (1966) (suggesting that only after the Court's "strikingly novel" interpretation of Section 5 and Morgan could Congress apply procedural requirements to prosecutions in state courts).

82 See generally Lawrence Lessig, Fidelity in Translation, 71 Tex L Rev 1165 (1993).

* Neither of the parties argued that the federal statute was applicable. In its brief, California contended that the state's "miscarriage of justice" harmless error standard should be applied, Respondent's Brief at 21-29, Chapman v California, 386 US 18 (1966), while Chapman contended that no constitutional error could be treated as harmless. Petitioner's Brief at 14-15, Chapman v California, 386 US 18 (1966).

386 US 58 (1967).

ss Id at 62 . See also Traynor, The Riddle of Harmless Error at 47 (cited in note 41 ). 
C. The "Harmless Beyond a Reasonable Doubt" Standard

After holding that the harmless error rule applicable to constitutional errors is a matter of federal law, the Chapman Court went on to find that some constitutional violations may be treated as harmless. While some "constitutional rights [are] so basic to a fair trial" that their infraction can never be treated as harmless, "there may be some constitutional errors which in the setting of a particular case are so unimportant and insignificant that they may, consistent with the Federal Constitution, be deemed harmless."

Next, the Chapman Court set out the federal harmless error standard: Before a constitutional error can be treated as harmless, the government bears the burden of establishing that the error is harmless beyond a reasonable doubt. While recognizing the oddity of requiring appellate court judges to apply a standard usually reserved for juries, it nonetheless said that the standard should be familiar to the courts and expressed its confidence that the standard would prove workable. ${ }^{87}$ Finally, applying this standard to the case before it, the Court found that the error could not be declared harmless, and therefore ordered a new trial. ${ }^{88}$

\section{The Mechanics of the Federal Harmless Error Standard}

Chapman left it to the federal courts to flesh out the details of the new federal constitutional harmless error standard. Yet, until last term, none of the subsequent Supreme Court cases that filled in the details of this standard included any reference to the uneasy constitutional status of the doctrine. Instead, subsequent decisions simply cite to the Court's decision in Chapman and proceed-much like any court exercising its traditional common law powers-to answer the many questions about harmless constitutional error left open by Chapman. What does it mean to say that an error is harmless? Does it mean that the error did not affect the jury? That the jury would have reached the same result without the error? That the result reached by the jury was correct, even if the jury was affected by the error? And how is an appeals court to know what factors the jury considered?

In conducting harmless error analysis, the appeals court looks at the evidence examined by the jury and determines whether the constitutional error contributed to the verdict. If the appeals court

\footnotetext{
so Chapman, 386 US at 22.

37 Id at 24.

${ }^{83}$ Id at 24-26.
} 
finds that the error played a role, it must order a new trial. The "question is not whether guilt may be spelt out of a record, but whether guilt has been found by a jury according to the procedure and standards appropriate for criminal trials." 89 Thus, if the jury did not, in fact, find the defendant guilty beyond a reasonable doubt, there "is no object, so to speak, upon which harmless-error scrutiny can operate."

Where evidence that should have been excluded was improperly admitted, the appeals court considers whether reliance on the improperly admitted evidence "contribute[d] to the verdict obtained."91 To this end, the court looks at the rest of the evidence in the record to determine whether a reasonable jury, with both the properly- and improperly-admitted evidence before it, would have relied on the evidence that was wrongfully introduced at trial. Yet to "say that an error did not 'contribute' to the ensuing verdict is not, of course, to say that the jury was totally unaware of that feature of the trial later held to have been erroneous." "92 Rather, it is only to find the error "unimportant in relation to everything else the jury considered on the issue in question, as revealed in the record." 93

In determining what parts of the record the jury considered, the appeals court does not ask the jurors about their deliberations, but instead imagines what a rational juror would do in the particular case before the court. ${ }^{94}$ Thus, "a court must approach [the inquiry] by asking whether the force of the evidence presumably considered by the jury in accordance with the instructions is so overwhelming as to leave it beyond a reasonable doubt that the verdict resting on that evidence would have been the same without the error."

so Carella v California, 491 US 263, 269 (1989) (Scalia concurring), quoting Bollenbach $v$ United States, 326 US 607, 614 (1946). See also Yates $v$ Evatt, 111 S Ct 1884, 1893 (1991) ("To satisfy Chapman's reasonable doubt standard, it will not be enough that the jury considered evidence from which it could have come to the verdict without reliance on the presumption. Rather, the issue under Chapman is whether the jury actually rested its verdict on evidence establishing [guilt] beyond a reasonable doubt . . . ."); Sullivan v Louisiana, 113 S Ct 2078, 2081 (1993) (the inquiry "is not whether, in a trial that occurred without the error, a guilty verdict would surely have been rendered, but whether the guilty verdict actually rendered in this trial was surely unattributable to the error") (emphasis in original).

${ }^{20}$ Sullivan, $113 \mathrm{~S} \mathrm{Ct}$ at 2082 (emphasis in original).

21 Chapman, 386 US at 24.

${ }^{22}$ Yates, $111 \mathrm{~S} \mathrm{Ct}$ at 1893.

${ }^{23}$ Id.

or Traynor, The Riddle of Harmless Error at 23 (cited in note 41).

os Yates, $111 \mathrm{~S} \mathrm{Ct}$ at 1893; Harrington v California, 395 US 250, 254 (1969) ("We of course do not know the jurors who sat. Our judgment must be based on our own reading of 
sonable jury could have returned a conviction, but rather whether the actual jury-assuming that it behaved reasonably-in fact returned a guilty verdict based on the permissibly introduced evidence. ${ }^{96}$

\section{E. Rule of Per Se Reversal}

While Chapman indicated that some constitutional rights are "so basic to a fair trial that their infraction can never be treated as harmless," be identified. ${ }^{98}$ Later cases, without ever making reference to the doctrine's uncertain constitutional position, continued to flesh out the line between those constitutional rights whose violation may be treated as harmless and those to which a rule of per se reversal is applied.

In Rose $v$ Clark, ${ }^{99}$ for example, the Court noted that most constitutional errors are susceptible to harmless error analysis: "[I]f the defendant had counsel and was tried by an impartial adjudicator, there is a strong presumption that any other errors that may have occurred are subject to harmless-error analysis." ${ }^{100}$ Constitutional deprivations that fundamentally alter the structure of the trial, however, may not be treated as harmless. "Harmless-error analysis [ ] presupposes a trial, at which the defendant, represented by counsel, may present evidence and argument before an impartial judge and jury." 101

Under current law, a given error is far less likely to be deemed a "structural" one requiring per se reversal if it is possible to measure the prejudicial impact of the error. This is the lesson of the controversial decision in Arizona $v$ Fulminante, ${ }^{102}$ where the Court held that the introduction of a coerced confession could be treated as harmless. Such an error may be harmless because the "evidentiary impact of an involuntary confession, and its effect upon the

the record and on what seems to us to have been the probable impact of the [error] on the minds of an average jury.").

or See Sullivan, $113 \mathrm{~S} \mathrm{Ct}$ at 2081 (Harmless error analysis does not ask "what effect the constitutional error might generally be expected to have upon a reasonable jury, but rather what effect it had upon the guilty verdict in the case at hand.").

87 386 US at 23 .

98 See Note, Harmless Constitutional Error: A Reappraisal, 83 Harv L Rev 814, 816 (1970).

478 US 570 (1986).

$100 \mathrm{Id}$ at 579 .

${ }^{101}$ Id at 578 (footnote omitted).

${ }^{102} 111 \mathrm{~S}$ Ct 1246 (1991). 
composition of the record, is indistinguishable from that of a confession obtained in violation of the Sixth Amendment--of evidence seized in violation of the Fourth Amendment-or of a prosecutor's improper comment on a defendant's silence at trial in violation of the Fifth Amendment." ${ }^{103}$ In such cases, the appeals court reviews "the remainder of the evidence against the defendant to determine whether the admission of the confession was harmless beyond a reasonable doubt."104 As long as it is possible to tell whether an error was harmless, appellate courts are to engage in harmless error analysis. ${ }^{105}$ In addition to these structural errors, violations that "cast[ ] a shadow upon the integrity of the judicial process," "106 such as racial discrimination in grand jury selection, also require per se reversal. ${ }^{107}$

\section{F. Are the Harmless Error Cases Constitutional Law?}

While Justice Traynor thought that Chapman was best seen as an interpretation of the federal harmless error statute, the re-

103 Id at 1265.

104 Id.

${ }^{105}$ See Charles J. Ogletree, Jr., Arizona v. Fulminante: The Harm of Applying Harmless Error to Coerced Confessions, 105 Harv L Rev 152, 162 (1991) ("[A] trial error seems to be one for which we can sometimes know for sure whether it has caused inaccuracy in a trial outcome, and a structural error seems to be one for which we can never know with any certainty."); Wayne R. LaFave and Jerold Israel, Criminal Procedure § 27.6(d) at 1170 (West, 2d ed 1992) ("The characteristic of 'structural' defects most frequently mentioned in Supreme Court opinions is their 'inherently indeterminate' impact upon the outcome of the trial.").

106 LaFave and Israel, Criminal Procedure \$ 27.6(d) at 1172.

${ }^{107}$ See Rose v Mitchell, 443 US 545 (1979); Vasquez v Hillery, 474 US 254 (1986). Furthermore, there are two additional discrete classes of cases to which harmless error analysis does not apply. First are those errors for which a new trial is not an appropriate remedy, like denial of the right to a speedy trial or multiple prosecution in violation of the Double Jeopardy Clause. In such cases, the remedy must include a bar on further prosecution, and the standard spelled out in Chapman therefore cannot be applicable. LaFave and Israel, Criminal Procedure $\S 27.6$ (d) at 1168. Second, there are those errors for which a showing of prejudice is a required element of the constitutional violation. For instance, since a defendant's right to the effective assistance of counsel is not denied unless she can show that prejudice resulted, see Strickland v Washington, 466 US 668 (1984), a violation of this right cannot be seen as harmless. By the same token, the prosecutor's duty to disclose exculpatory evidence has not been violated unless the evidence would be helpful to the defense. See United States $v$ Bagley, 473 US 667 (1985). Thus, a violation of this right may not be seen as harmless. Compare United States $v$ Valenzuela-Bernal, 458 US 858 (1982), where the Court said that government activity interfering with the defendant's ability to call witnesses does not violate the government's duty unless the evidence lost "would be both material and favorable to the defense." Id at 873. Here, a showing of error is not tantamount to a showing of harm, since the evidence might be material and favorable yet cumulative. One can therefore imagine a small class of cases in which it would be possible to engage in harmless error analysis in this circumstance. 
cent Supreme Court decisions explicating the harmless error standard-excepting only one recent decision discussed in Section III.C.-make no reference to the statute. ${ }^{108}$ In addition, the language of the statute directs courts to ignore errors that do not "affect the substantial rights of the parties."109 Whatever one might say about the Court's complicated harmless constitutional error jurisprudence, these cases are not about figuring out what Congress meant, in 1919, by "affect the substantial rights of the parties."

Instead, the Court appears to treat the federal harmless error standard like any other constitutional rule. The recent cases cite neither to the federal statute nor to Chapman's reference to Congress's power to impose a different rule. ${ }^{110}$ This omission suggests that the Court thinks of the doctrine as a constitutional rule, since when the Court exercises its federal common law authority, it is typically careful to rely on a relevant congressional statute as a touchstone. For example, in a recent admiralty case where wrongful death was alleged, the Court refused to create a common law right of recovery for lost future income. There, the Court noted that it "sail[s] in occupied waters. Maritime tort law is now dominated by federal statute, and we are not free to expand remedies at will . . . ."111

It is surely possible to treat the harmless error rule in constitutional terms, to see the harmlessness standard as "part and parcel" of underlying constitutional rights. ${ }^{112}$ For example, one commentator has argued that "constitutional rights [such as the right against compelled self-incrimination] can be defined so as to in-

\footnotetext{
${ }^{108}$ Furthermore, were the harmless error doctrine a matter of statutory construction, the Court's willingness to depart from well-settled precedent that coerced confessions could never be treated as harmless would be difficult to understand, given the heightened deference traditionally paid to statutory precedents. See Burnet v Coronado Oil \& Gas Co., 285 US 393, 406 (1932) (Brandeis dissenting); Square D Co. v Niagara Frontier Tariff Bureau, Inc., 476 US 409, 424 n 34 (1986); Lawrence C. Marshall, "Let Congress Do It": The Case for an Absolute Rule of Statutory Stare Decisis, 88 Mich L Rev 177 (1989). Note, however, that this heightened deference paid to statutory precedents is lowered somewhat when courts interpret language as broad as that used in $\$ 2111$. See, for example, Monroe v Pape, 365 US 167, 187 (1961) (holding that municipal corporations were not "persons" for the purposes of $\S 1983$ ); Monell v Department of Social Services, 436 US 658, 663 (1978) (overruling Monroe).

${ }^{209} 28$ USC \& 2111.

110 The only exception to this is the Seventh Circuit's declaration in Brecht $v$ Abrahamson, 944 F2d 1363, 1374 (7th Cir 1991), aff'd 113 S Ct 1710 (1993) that its discussion of the proper standard of review for harmlessness on collateral review would "be academic if Congress or the Supreme Court has directed the application of the Chapman standard" (emphasis added).

111 Miles v Apex Marine Corp., 111 S Ct 317, 327 (1990).

${ }^{112}$ See Strickland, 466 US at 691-96.
} 
clude a harmless error standard. Thus, the right against compelled self-incrimination could be defined as a right ... not to be convicted when it cannot be proved 'beyond a reasonable doubt' that compelled self-incrimination 'did not contribute to the verdict." "113

In a few cases, in fact, the Court has adopted precisely this approach. For example, in order to make out a claim that a defendant's Sixth Amendment right to effective assistance of counsel has been violated, a criminal defendant needs to show not only that her counsel's performance was deficient, but also that "the deficient performance prejudiced the defense."114 Thus, a defendant cannot show a Sixth Amendment violation unless whatever error might have occurred was not harmless. At least in this context, the harmless error standard has become part of constitutional law.

But aside from those few circumstances where a harmless error or "prejudice" standard has been expressly built into the definition of the underlying constitutional right, the following section argues, the harmless error doctrine should continue to be seen in the way the Chapman Court conceived of it: as constitutional common law.

\section{The Original Conception Reconceived: Harmless Error as Constitutional Common Law}

\section{A. The Category of Constitutional Common Law}

Why has the harmless error standard come to be seen in constitutional terms? Perhaps the answer lies in Professor Monaghan's description of the mystique of the Supreme Court. According to Monaghan, the Court's "great prestige has fostered the impression that every detailed rule laid down has the same dignity of the constitutional text itself."115

Yet this is a false impression. In his landmark article on the constitutional common law, Monaghan argues that much "of what passes as authoritative constitutional 'interpretation' is best understood as something of a quite different order-a substructure of substantive, procedural, and remedial rules drawing their inspiration and authority from, but not required by, various constitu-

\footnotetext{
113 Mause, 53 Minn L Rev at 532 (cited in note 58), quoting Chapman, 386 US at 24.

11 Strickland, 466 US at 687; see also note 107.

11 Monaghan, 89 Harv L Rev at 2 (cited in note 6).
} 
tional provisions; in short, a constitutional common law subject to amendment, modification, or even reversal by Congress."116

While Monaghan's description of this category of rules does not expressly include the harmless constitutional error doctrine, the doctrine should be understood in precisely these terms. So understood, the harmless error doctrine is subject to all of the same criticisms that have been levied against the categories of constitutional common law that Monaghan identified. Thus, Justice Harlan criticized the Chapman majority in the same terms Professor Grano employed to attack the legitimacy of the prophylactic constitutional common law rule announced in Miranda $v$ Arizona. Harlan chastised the Chapman majority:

The primary responsibility for the trial of state criminal cases still rests upon the States, and the only constitutional limitation upon these trials is that the laws, rules and remedies applied must meet constitutional requirements. If they do not, this Court may hold them invalid. The Court has no power, however, to declare which of many admittedly constitutional alternatives a state may choose. ${ }^{117}$

Echoes Professor Grano:

In reviewing a state criminal conviction, the Court's authority, simply and exhaustively stated, is to determine whether the Constitution has been violated. Whatever its personal view of the state proceedings, the Court must affirm a state conviction absent a federal violation. ${ }^{118}$

Neither Grano's extended attack on the use of prophylactic rules in criminal procedure ${ }^{119}$ nor any of the other literature on the

${ }^{116}$ Id at 2-3. Note that there is a vigorous debate about the legitimacy of applying such constitutional common law rules to the states. This issue is explored in detail in the exchange over the legitimacy of the Court's decision in Miranda $v$ Arizona. See Joseph D. Grano, Prophylactic Rules in Criminal Procedure: A Question of Article III Legitimacy, 80 Nw U L Rev 100 (1985); Stephen J. Schulhofer, Reconsidering Miranda, 54 U Chi L Rev 435 (1987); Joseph D. Grano, Miranda's Constitutional Difficulties: A Reply to Professor Schulhofer, 55 U Chi L Rev 174 (1988); David A. Strauss, The Ubiquity of Prophylactic Rules, 55 U Chi L Rev 190 (1988).

117 Chapman, 386 US at 47-48 (Harlan dissenting).

118 Joseph D. Grano, Miranda v. Arizona and the Legal Mind: Formalism's Triumph over Substance and Reason, 24 Am Crim L Rev 243, 252 (1987) (emphasis in original). Note that the prophylactic nature of the Miranda rule led some to believe that it could be reversed by legislation. See discussion in note 27 .

119 Grano, $80 \mathrm{Nw}$ U L Rev 100. 
constitutional common law powers of the federal courts ${ }^{120}$ includes discussion of the harmless error doctrine. This omission is strong evidence of the way in which harmless error has (mistakenly) come to be seen as a simple matter of constitutional interpretation.

\section{B. Bivens and Constitutional Common Law}

Further support for the view of harmless constitutional error rules as "constitutional common law" can be found in the close analogy between the harmless error doctrine and the paradigmatic example of constitutional common law: the Court's decision in Bivens $v$ Six Unknown Named Agents of Federal Bureau of Narcotics. ${ }^{121}$ In Bivens, the plaintiff sought damages in federal district court, alleging that federal narcotics agents had deprived him of his Fourth Amendment rights by conducting an unreasonable search. ${ }^{122}$ Because $\S 1983$ only applies to state officers, Bivens sought a damages remedy implied from the Fourth Amendment directly. ${ }^{123}$ The federal officers insisted that Bivens could only bring a state law tort claim. ${ }^{124}$

The Court rejected this argument, finding that it rested on "an unduly restrictive view of the Fourth Amendment's protection against unreasonable searches and seizures."125 Writing for the Court, Justice Brennan noted that damages "have been regarded as the ordinary remedy for an invasion of personal interests in liberty," and that while the Fourth Amendment does not "in so many words provide for its enforcement by an award of money damages," courts should be free to "use any available remedy to make good the wrong done."126

Finally, the Court rejected the argument that the damages remedy should only be available if there were no other way to enforce the Fourth Amendment. In the absence of a congressional declaration that money damages should not be available, the issue became whether the court should vindicate the Fourth Amendment "through a particular remedial mechanism normally availa-

${ }^{120}$ See generally Monaghan, 89 Harv L Rev at 1 (cited in note 6); Thomas S. Schrock and Robert C. Welsh, Reconsidering the Constitutional Common Law, 91 Harv L Rev 1117 (1978); Thomas W. Merrill, The Common Law Powers of Federal Courts, 52 U Chi L Rev 1 (1985); Strauss, 55 U Chi L Rev 190 (cited in note 116).

121403 US 388 (1971).

122 Id at $389 \mathrm{n} 1$.

223 Id at 389; see 42 USC § 1983 (1988).

124403 US at 390.

125 Id at 391 .

${ }^{128}$ Id at 395-96, quoting Bell $v$ Hood, 327 US 678, 684 (1946). 
ble in the federal courts."127 Justice Harlan concurred, noting that the question for him was "whether compensatory relief is 'necessary' or 'appropriate' to the vindication of the interest asserted."128 Finding that it was, he would have allowed an action for money damages.

In a sense, Bivens is similar to Chapman. In both cases the Court apparently thought that its duty to protect the underlying right was sufficient authority to announce a remedial rule. Yet in both cases, the remedy should not be seen as a necessary imperative of the Constitution, but as a matter of constitutional common law. This, in any case, is how Professor Monaghan described the Bivens decision: "[U]nless the Court views a damage action as an indispensable remedial dimension of the underlying guarantee, it is not constitutional interpretation, but common law." "229 The same can certainly be said of Chapman.

Because Bivens is a constitutional common law decision, familiar questions arise about Congress's authority to provide an alternative remedy. According to Professor Dellinger, Congress would have this power as long as its remedy adequately protected the right: "Congress may legislate an alternative remedial scheme which it considers equally effective in enforcing the Constitution and which the Court, in the process of judicial review, deems an adequate substitute for the displaced remedy."130 Precisely the same analysis should govern Congress's authority to substitute the Court's harmless error rule with one of its own crafting.

Indeed, at least in the Bivens context, the Supreme Court has agreed with Professor Dellinger's assessment. In Bush v Lucas, ${ }^{131}$ a federal employee was demoted after speaking unfavorably about the agency in which he was employed. In an administrative appeal of his demotion, Bush received a $\$ 30,000$ back pay award. ${ }^{132}$ While that appeal was pending, however, he brought a Bivens action, claiming a denial of his First Amendment rights. ${ }^{133}$ The Supreme Court, assuming that his First Amendment rights were denied and that the administrative remedy did not provide full compensa-

127403 US at 397.

${ }^{128}$ Id at 407 (Harlan concurring).

129 Monaghan, 89 Harv $L$ Rev at 24 (cited in note 6) (footnotes omitted). But see Schrock and Welsh, 91 Harv L Rev 1117 (cited in note 120).

${ }_{130}$ Walter E. Dellinger, Of Rights and Remedies: The Constitution as a Sword, 85

Harv L Rev 1532, 1552-53 (1972).

131462 US 367 (1983).

132 Id at 371.

13s Id at 372. 
tion, ${ }^{134}$ nonetheless denied the availability of a supplemental Bivens remedy: "The question is not what remedy the court should provide for a wrong that would otherwise go unredressed. It is whether an elaborate remedial system that has been constructed step by step, with careful attention to conflicting policy considerations, should be augmented by the creation of a new judicial remedy for the constitutional violation at issue."135 Because the remedial regime set out by Congress "provides meaningful remedies for employees who may have been unfairly disciplined for making critical comments about their agencies," ${ }^{138}$ Congress could permissibly replace the Bivens action with this administrative remedy. ${ }^{137}$

\section{Harmless Error as Constitutional Common Law: The Case From Brecht v Abrahamson}

Chapman strongly suggests that the harmless error doctrine falls within Professor Monaghan's conception of "a constitutional common law subject to amendment, modification, or even reversal by Congress."138 Recall that in Chapman, the Court found that the defendants' rights not to have the prosecutor comment on their failure to testify at trial were federal rights that, "in the absence of appropriate congressional action, it is [the Court's] responsibility to protect by fashioning the necessary rule."139

This language makes clear that the Court saw its role merely as interposing a prophylactic remedial rule to protect the underlying constitutional right. ${ }^{140}$ Moreover, the Court interposed the rule without undertaking an interpretation of the defendant's Fifth Amendment right against self-incrimination. When the Court announces a constitutional rule, it does not hem and haw about whether there has been "appropriate congressional action." Whether or not Congress has responded is irrelevant to constitutional interpretation. Thus, the Court's language indicates that the doctrine emerging from Chapman should be seen as a matter of

134 Id.

138 Id at 388 .

1 s6 Id at 386 .

${ }^{137}$ See also Carlson v Green, 446 US 14, 18-19 (1980). There, in permitting a Bivens action for Eighth Amendment violations, the Court said that the action can be defeated when "Congress has provided an alternative remedy which it explicitly declared to be a substitute for recovery under the Constitution and viewed as equally effective." (emphasis omitted).

138 Monaghan, 89 Harv L Rev at 3 (cited in note 6).

139 386 US at 21.

140 See generally Strauss, 55 U Chi L Rev 190 (cited in note 116). 
constitutional common law, rather than a direct interpretation of the Constitution.

Brecht $v$ Abrahamson, decided in the last term, suggests the Court's view of the constitutional status of the harmless error rule. ${ }^{141}$ There, the Court declared that on habeas review, a federal court is to let a state conviction stand unless a constitutional violation "had substantial and injurious effect or influence in determining the jury's verdict."142 This standard, drawn from the interpretation of the federal harmless error statute, is less stringent than the Chapman "beyond a reasonable doubt" standard.

Yet, while the Brecht Court found the federal statutory standard applicable, the decision is not an interpretation of that statute. Instead, the Court merely declared that this lesser standard "is better tailored to the nature and purpose of collateral review than the Chapman standard, and application of a less onerous harmless-error standard on habeas promotes the considerations underlying our habeas jurisprudence." 143

In reaching this conclusion, the Court took note of the various interests that weigh against upsetting state criminal convictions on collateral attack: "the State's interest in the finality of convictions that have survived direct review within the state court system"144 as well as "comity and federalism."145 In light of these interests, the Court declared that "it scarcely seems logical to require federal habeas courts to engage in the identical approach to harmless-error review that Chapman requires state courts to engage in on direct review." "148 Brecht, then, should be seen as an interpretation of the habeas corpus statute-not the harmless error statute. The habeas corpus statute empowers federal courts to grant habeas relief to those who are "in custody in violation of the Constitution or laws . . . of the United States."147

Brecht, therefore, raised the implicit question of whether the harmless constitutional error rule is part of the Constitution. If the harmless error doctrine were constitutional law, then the habeas statute-by its use of the phrase "in violation of the Constitu-

${ }^{141} 113 \mathrm{~S}$ Ct 1710 (1993).

${ }^{142}$ Id at 1714, quoting Kotteakos v United States, 328 US 750, 776 (1946).

${ }_{143} 113 \mathrm{~S} \mathrm{Ct}$ at 1714. The federal habeas corpus statute provides that habeas relief is available to those "in custody in violation of the Constitution or laws or treaties of the United States." 28 USC § 2241 (1988).

$144113 \mathrm{~S}$ Ct at 1720.

145 Id.

${ }^{168}$ Id at 1721.

${ }^{247} 28$ USC § 2241 (emphasis added). 
tion"-would incorporate the harmless error standard. Thus, any person who was convicted after constitutional error, so long as that error was not harmless beyond a reasonable doubt, would be in custody in violation of the Constitution. On this interpretation, the Chapman "beyond a reasonable doubt" standard would have to apply on habeas review just as it does on direct appeal.

But the Brecht Court did not apply this analysis. Instead, the Court engaged in statutory interpretation of the habeas statute-implicitly concluding that the harmless error standard is not a matter of constitutional law. Reading the statute, the Court found that the language "custody in violation of the Constitution" did not incorporate any harmless error standard. ${ }^{148}$ Rather, the Court would have to determine whether the relationship between the underlying constitutional error and the "custody" at issue constituted "custody in violation of the Constitution." If the violation did not have a "substantial and injurious effect" on the verdict, then the custody was not in violation of the Constitution. ${ }^{148}$

In separate dissents, Justices White and O'Connor both pointed clumsily to the uneasy constitutional status of the harmless error doctrine. Justice White rested his dissent on the simple fact that whether or not the harmless error doctrine is part of the "Constitution" the Chapman standard is nonetheless a matter of "federal law." Therefore, a "defendant whose conviction has been upheld despite the occurrence of [a constitutional violation that is not harmless beyond a reasonable doubt] is "in custody in violation of the Constitution or laws . . . of the United States.' "150

White's analysis simply assumes its conclusion-that the Chapman standard is a "law" that applies on habeas review. In fact, it can be argued strongly that Chapman, by its own terms, ought not to apply to habeas cases. The Chapman Court interposed its standard only because the federal government has a constitutional obligation to protect constitutional rights. Given "the absence of appropriate congressional action" in Chapman, it fell to the Court to fashion a rule that met this obligation. ${ }^{161}$ But in cases where Congress has acted (such as habeas corpus), the Court's task would be limited to deciding how to interpret that action. The Chapman rule-interposed only because Congress was silent-would not apply.

\footnotetext{
$16113 \mathrm{~S} \mathrm{Ct}$ at 1718.

140 Id at 1714.

180 Id at 1726 (White dissenting) (emphasis added), quoting 28 USC § 2254(a)(1988).

131 Chapman, 386 US at 21.
} 
Justice O'Connor focused her dissent on the proper construction of the language "custody in violation of the Constitution." Perhaps failing to realize that the majority implicitly resolved the matter, Justice O'Connor objected to the fact that the Court did not expressly declare whether the harmless error doctrine was a matter of constitutional interpretation or constitutional common law. "We are left to speculate whether Chapman is the product of constitutional command, or a judicial construct that may overprotect constitutional rights." 152

According to Justice O'Connor, because the Court had for twenty-five years read the habeas statute to require the application of the Chapman standard, ${ }^{153}$ a sudden reinterpretation of this statute-especially in light of congressional silence ${ }^{154}$ - smacked of judicial activism. Thus, "restraint should control our decision today." 155 Seeing no reason why the habeas statute should be read to impose a lesser standard, Justice O'Connor called for the retention of the Chapman standard in habeas cases: "Because I am not convinced that the principles governing the exercise of our habeas powers-federalism, finality, and fairness-counsel against applying Chapman's harmless-error standard on collateral review, I would adhere to our former practice of applying it to cases on habeas and direct review alike."156

The Court in Brecht faced the question of the constitutional status of the harmless error doctrine for the first time since Chapman, but failed to resolve it explicitly. Brecht's treatment of harmless error, however, strongly indicates that the doctrine is not an interpretation of the Constitution itself, but rather a prophylactic rule designed to protect underlying constitutional rights-a constitutional common law doctrine. Therefore, even if the cases after Chapman "sound" like constitutional law, they should not be read to alter Chapman's constitutional common law nature.

${ }^{162}$ Brecht, $113 \mathrm{~S} \mathrm{Ct}$ at 1729 (O'Connor dissenting).

${ }^{163}$ The Chapman standard had been applied consistently in habeas cases beginning" with Anderson v Nelson, 390 US 523 (1968) (per curiam).

164 The Brecht majority expressly rejected the proposition that an inference of acquiescence should be drawn from congressional silence. $113 \mathrm{~S} \mathrm{Ct}$ at 1719. See also Frank H. Easterbrook, Stability and Reliability in Judicial Decisions, 73 Cornell L Rev 422, 427-29 (1988).

${ }^{186} 113 \mathrm{~S} \mathrm{Ct}$ at 1728 (O'Connor dissenting).

${ }^{168}$ Id at 1729 ( $0^{\prime}$ Connor dissenting). 


\section{Conclusion}

Title IX seems innocuous enough, as one of the countless legislative efforts to reverse a Supreme Court decision with which Congress was unhappy. ${ }^{167}$ Yet the legislation raises a surprising number of thorny questions about the extent of Congress's powers.

The questions are hardest if one thinks the harmless error doctrine is a matter of constitutional law, part and parcel of the underlying right. If this were true, the legislation would be constitutionally permissible only if one were to accept a broad reading of Congress's powers under Section 5 of the Fourteenth Amendment. Fortunately, however, a proper understanding of the constitutional common law nature of the harmless error doctrine allows one to elide this more controversial matter.

In this case, Congress's authority to provide an adequate remedy by appropriate legislation is plain. Even if one accepts only the modest Model 1 vision of Congress's Section 5 power, Congress has the authority to alter constitutional common law through legislation. Therefore, Congress can reverse Fulminante and require states to grant a defendant a new trial if a coerced confession is introduced against him. ${ }^{158}$ The only limitation is that if Congress were to provide a lesser remedy than the one provided by the Court (by enacting a more expansive harmless error rule), ${ }^{159}$ its remedy would need to adequately vindicate constitutional rights.

The constitutional common law nature of the harmless error rule has received very little attention. ${ }^{160}$ While early commentators

${ }^{157}$ See generally Abner J. Mikva and Jeff Bleich, When Congress Overrules the Court, 79 Cal L Rev 729 (1991); Comment, 141 U Pa L Rev 1029 (cited in note 35).

${ }^{188}$ While it is arguable that such a law affects the procedural mechanisms of state trials in violation of the doctrine of Erie Railroad v Tompkins, 304 US 64 (1938), this concern is a red herring. Chapman firmly declares that the harmless error standard to be applied to violations of federal constitutional rights is a matter of federal law. Any inconsistent state law would therefore be preempted under the Supremacy Clause. US Const, Art VI.

${ }^{158}$ Both Professor Mause and Justice Traynor raise this question. See Mause, 53 Minn L Rev at 527 (cited in note 58) ("It is interesting to speculate on the Court's reaction to a federal statute redelegating the power to fashion harmless error rules to the states."); Traynor, The Riddle of Harmless Error at 46 (cited in note 41) ("Would it be 'appropriate congressional action' to prescribe a highly probable test for harmless error? A more probable than not test? Or even a rule of automatic reversal? Could Congress instead leave the formulation of tests to the states by adopting, for example, Mr. Justice Harlan's view that a state harmless-error rule is an independent and adequate state ground on which to base an affirmance if the state rule is consistent with due process and reasonably applied?").

${ }^{180}$ This is particularly striking when one considers the importance of the doctrine. One commentator predicts that it is involved in up to ten percent of all criminal appeals. See Goldberg, $71 \mathrm{~J}$ Crim L \& Criminology at 421 (cited in note 42). 
noted the precarious constitutional status of the doctrine, ${ }^{101}$ the harmless error rule has typically been excluded from discussions of the constitutional common law powers of the federal courts. This is just an oversight, since the harmless error doctrine-like Bivens-is simply about what remedies are to be afforded once it is agreed that someone has been deprived of a constitutional right.

While the Court is surely correct, in the absence of appropriate congressional action, to step in and provide a remedy, Congress must reserve the power to adjudge the judicial remedy inadequate. Title IX reflects a congressional judgment that the Fifth Amendment is not sufficiently vindicated if an appeals court judge is permitted to say that the admission of a coerced confession against a defendant was somehow a harmless error.

161 See Mause, 53 Minn L Rev at 527-37 (cited in note 58); Traynor, The Riddle of Harmless Error at $37-49$ (cited in note 41). 